\title{
REMISSION OF LATE-ONSET POST-LIVER TRANSPLANTATION NON-HODGKIN LYMPHOMA
}

\author{
Kalina Grivcheva Stardelova ${ }^{1}$, Aleksandar Stojanovik ${ }^{2}$, Rozalinda Popova Jovanovska ${ }^{1}$, \\ Sonja Stavrik ${ }^{2}$, Magdalena Dimitrova ${ }^{1}$, Neda Milevska Kostova ${ }^{3}$, Vladimir Serafimoski ${ }^{4}$ \\ ${ }^{1}$ University Clinic for Gastroenterohepatology, Ss. Cyril and Methodius University, Skopje, R. Macedonia \\ ${ }^{2}$ University Clinic for Haematology, Ss. Cyril and Methodius University, Skopje, R. Macedonia \\ ${ }^{3}$ Centre for Regional Policy Research and Cooperation "Studiorum", Skopje, R. Macedonia \\ ${ }^{4}$ Macedonian Academy of Sciences and Arts, Skopje, R. Macedonia
}

Corresponding author: Kalina Grivcheva Stardelova, e-mail: kalina.stardelova@gmail.com

\begin{abstract}
We describe the clinical course of a patient who developed high-grade lymphoma during immunosuppression treatment with cyclosporine A, following liver transplantation. After anti-neoplastic polychemotherapy treatment, the remission of lymphoma was confirmed and maintained for over four years.

The patient, a 27 year old female had liver transplantation at the age of 17, due to acute liver failure, caused by non-diagnosed Wilson disease. Nearly seven years post-transplantation, the patient was diagnosed with non-Hodgkin B-cell lymphoma (NHBCL), potentially induced by Cephalosporin A therapy. After the treatment with rituximab and $\mathrm{CHOP}$ therapy (r-CHOP protocol), remission was determined using computer tomography. Remission is maintained to date.

A review of reported cases of post-transplant lymphoproliferative disorders (PTLDs) in liver transplanted (LT) patients showed that the onset of PTLDs is the highest in the first year after transplantation. In addition, remission rates of NHBCL in LT patients are not much elaborated in the literature.

It is our opinion that the presented case is rare, both from the aspect of timeline of occurrence of the PTLD and the achieved remission, using $\mathrm{r}-\mathrm{CHOP}$ protocol.
\end{abstract}

Keywords: liver; transplants; lymphoma, Non-Hodgkin; immunosuppression

\section{INTRODUCTION}

Long-term survival of liver transplant recipients is threatened by increased rates of de-novo malignancy and recurrence of hepatocellular carcinoma, both events tightly related to immunosuppression [1-3]. Post-transplant lymphoproliferative disorders (PTLDs) are a well-recognized and potentially life-threatening morbidity that can occur following the transplantation of allogeneic hematopoietic stem cells and solid organs, including the liver [4, 5]. PTLDs constitute a heterogeneous group of lymphoid lesions, ranging from early lesions and pol- ymorphic PTLDs to monomorphic lymphomas and classical Hodgkin lymphomas [6]. Non-Hodgkin's lymphoma (NHL) can also occur in solid organ transplant recipients, with six-fold higher risk following transplantation, than in the general population [3].

PTLDs are commonly associated with the administered immunosuppression therapy [2] and Epstein Barr Virus (EBV) infection [7]. However, a substantial minority of PTLDs is not associated with EBV and represents a unique disease entity [8-11]. In the current literature, the clinical presentation of 
EBV-negative PTLDs has not been characterised as well as by EBV-positive cases [7]. Luskin et al (2015) in their study on 176 adult solid organ transplant recipients diagnosed with PTLDs between 1990 and 2013 have identified an increase of proportion of EBV-negative cases [9], making this group more interesting for study and presentation through case reports. In addition, cyclosporine-induced malignancies have been investigated largely for bone marrow transplantations, kidney and heart transplantations $[11,12]$. Several studies have shown that liver transplanted (LT) patients are at increased risk for the development of PTLDs immediately after transplantation [12-14]. According to literature, mortality rates range from 40-70 percent in patients with solid organ transplants, and NHLs in transplanted patients have a poorer outcome, than other NHLs [15].

The PTLDs incidence in LT patients is the highest immediately after transplantation $[14,16]$. Compared to lymphomas developing in the normal population, PTLDs usually have a more unfavourable histopathological presentation, a more aggressive clinical course, lesser responsiveness to conventional interventions, and a poorer outcome [16].

The presented case shows late onset of nonHodgkin lymphoma in a liver transplanted patient, with complete remission longer than 4 years post-healing.

\section{CASE REPORT}

We report the clinical course of a patient who developed high-grade large B-cell lymphoma during immunosuppression treatment with cyclosporine A, following liver transplantation who underwent anti-neoplastic polychemotherapy treatment, with maintained remission.

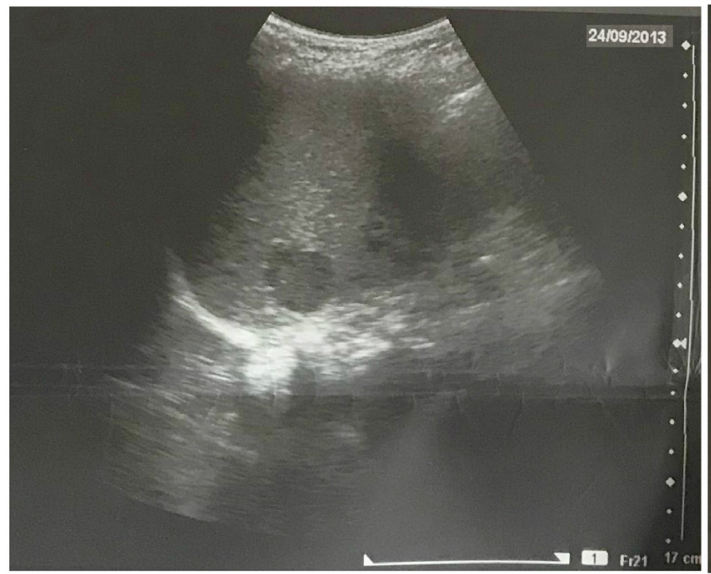

Figure 1. Hypoechogenic zone in the subfrenium (ultrasonography scans: 24 September 2013 (left) and 1 November 2013 (right))

The patient, a previously healthy 17 year old Caucasian female was admitted to our department in May 2007 with a mild recurring icterus. Wilson disease was suspected, but initial biochemical analysis showed normal urinary copper and ceruloplasmin levels. Two weeks post-admission, the patient's condition worsened in sepsis and comatose state with bilirubin levels of over $700 \mathrm{mmol} / \mathrm{L}$, indicating liver transplantation. Living donor liver transplantation was performed in late June 2007 in the Clinical Hospital Centre Merkur in Zagreb, Croatia.

In the post-operative period, the patient developed portal vein stenosis, a not very common complication of liver transplantation [17], which was successfully stented and treated with standard dosage of anticoagulant therapy clopidogrel (Zyllt®).

Based on the clinical guidelines, immunosuppression therapy was administered post-transplantation; Cyclosporin A treatment was based on protocol during hospitalisation and early post-transplantation period, with dosages of $2 \times 200 \mathrm{mg}$ per day, that were gradually reduced to $2 \times 100 \mathrm{mg}$ per day. This treatment protocol was maintained until the diagnosis of non-Hodgkin lymphoma (NHL), when it was reduced to $2 \times 50 \mathrm{mg}$ per day for six months and then to $2 \times 25 \mathrm{mg}$ per day from April 2016 to date.

Cyclosporine concentration in the blood was regularly monitored. Before the diagnosis of the NHL, the therapy regimen was $200 \mathrm{mg}$ a day, with average cyclosporine blood concentrations of 84.3 $\mathrm{ng} / \mathrm{ml}$ (range: 66.0-150.1 ng/ml, median: $77.9 \mathrm{ng} /$ $\mathrm{ml}$ ). After the diagnosis, when the cyclosporine dosages were reduced to $50 \mathrm{mg}$ per day, the average concentration of cyclosporine was $16.5 \mathrm{ng} / \mathrm{ml}$ (range: 7.1-33.2 ng/ml, median: $13.9 \mathrm{ng} / \mathrm{ml})$.

Initial and regular tests for Cytomegalovirus (CMV) and Epstein-Barr virus (EBV) returned with negative results at each testing. This excluded EBV,

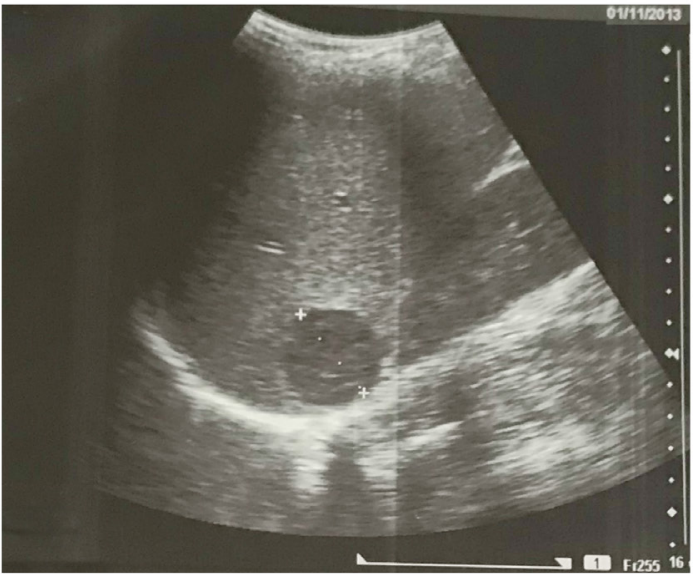


as a reason of NHBCL occurrence, leading to a conclusion that the lymphoma was potentially caused by cyclosporine therapy.

Routine ultrasound controls and blood tests were performed every six months post-transplantation. In all controls the biliary tract, pancreas and kidneys appeared with normal dimensions and function. In one of the controls in late 2013, around seven years after transplantation, a package of intra-abdominal lymph nodes was detected (Fig. 1).

Histopathological evaluation after fine needle biopsy showed occurrence of NHL (Fig. 2). The immunohistochemical analysis confirmed diffuse lymphocyte CD20 positivity and negative CD3 staining. Proliferative index of Ki-67 was 50-55\%, and bcl-2 suppressor gene was found in $60-65 \%$ of lymphocytes. The results inferred presence of large B-cell lymphoma.

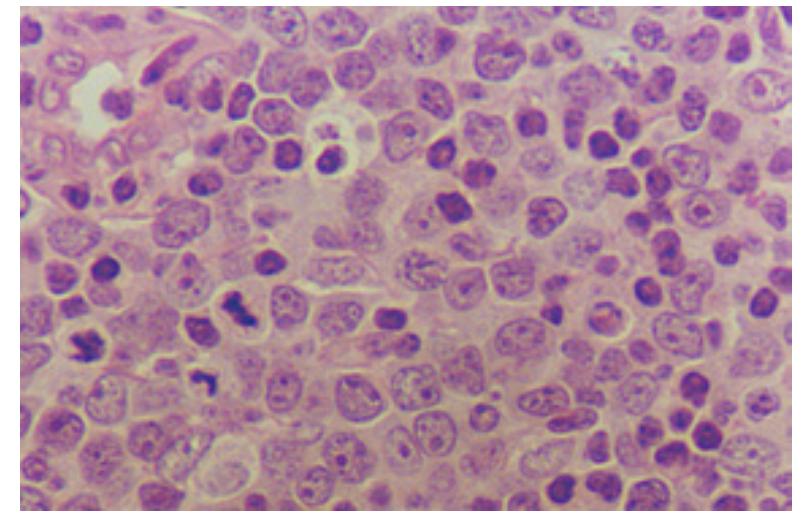

Figure 2. Detection of Non-Hodgkin large B-cell lymphoma using haematoxylin-eosin staining (magnification: 400x, 11 December 2013)

The patient was referred to the University clinic for haematology and treated with CHOP (cyclophosphamide - $1300 \mathrm{mg}$, doxorubicin - 90 $\mathrm{mg}$, vincristine $-2 \mathrm{mg}$, and prednisolone -100 $\mathrm{mg}$ p.o. for 5 days) regimen and monoclonal antibody rituximab anti-CD20 (700 mg). After seven cycles of combined therapy, the disease was in complete remission, confirmed with computer tomography of abdomen in late 2014 (Fig. 3).

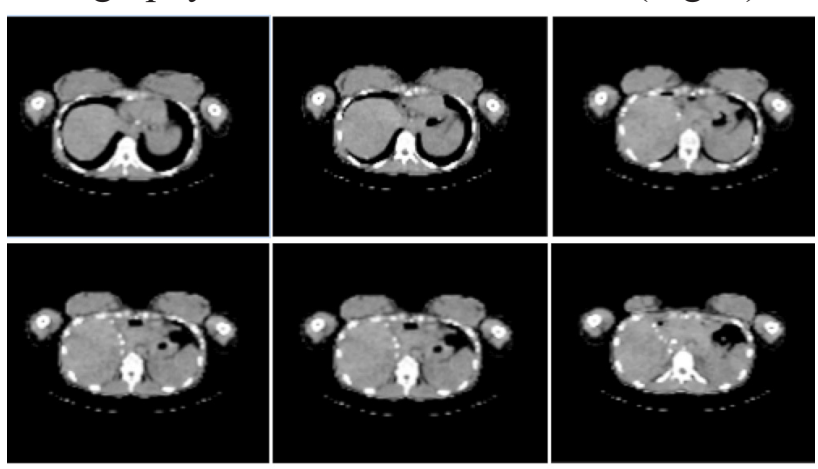

Figure 3. Computer tomography of abdomen after treatment (29 September 2014), normal results
The patient has been under regular monitoring and has shown no signs of relapse after over four years, since the confirmation of the remission.

\section{DISCUSSION}

As part of liver transplantation, immunosuppression is given to prevent graft rejections [18], and studies have shown that it is associated with a variety of adverse effects [19] and increased risk of infections and malignancy $[1,18]$. PTLDs have been reported to occur at a higher rate $(8-25 \%)$ in heart, lung, intestinal, and multi-organ transplants, compared to incidence rate of $1-5 \%$ in kidney and liver transplants [20]. On the other hand, lymphoma in solid-organ transplant recipients represents $21 \%$ of all cancer types, as compared with $4 \%$ among women and 5\% among men in the general population [15].

Literature describes several risk factors for PTLDs occurrence, among which strong evidence exists for EBV infection and intensity of immunosuppression therapy. EBV seronegativity before transplantation in solid-organ transplant recipients is an important predisposing factor of PTLDs, leading to an increase in risk by a factor of 10 to 75 , as compared with the risk among seropositive recipients [21]. A recent review of literature found that the contribution of different immunosuppression agents, such as calcineurin inhibitors (cyclosporine and tacrolimus) or mTOR inhibitors (everolimus and serolimus) is not clear, and that induction therapy plays a major role in the early development of PTLDs, whereas late development is likely to be related to cumulative immunosuppression [15].

LT patients have the highest incidence of PTLDs immediately after transplantation $[14,16]$. Compared to lymphomas developing in the normal population, PTLDs usually have a more unfavourable histopathological presentation, a more aggressive clinical course, lesser responsiveness to conventional interventions, and a poorer outcome [16]. The rarity of this case is also reflected in the fact that of all 23 liver transplanted patients in Macedonia (21 survived), who are registered and monitored for the entire post-transplantation period, this patient is the only one with occurred PTLD, as a possible consequence of the immunosuppression therapy. The described case of late-onset post-transplant lymphoproliferative disorder was successfully treated with complete remission for over four years post-treatment. 


\section{CONCLUSION}

Long-term effects of general vibration can negatiA review of reported cases of post-transplant lymphoproliferative disorders (PTLDs) in LT patients showed that the onset of PTLDs is the highest in the first year after transplantation. In addition, remission rates of non-Hodgkin lymphoma in LT patients are not much elaborated in the literature. It is our opinion that the presented case is rare, both from the aspect of timeline of the PTLDs occurrence and the achieved remission, using r-CHOP protocol.

\section{REFERENCES}

1. Rodríguez-Perálvarez M, De la Mata M, Burroughs AK: Liver transplantation: immunosuppression and oncology. Current opinion in organ transplantation 2014, 19(3):253.

2. Gallego-Melcon S, Sanchez de Toledo J, Martinez V, Moraga F, Iglesias J, Ruiz C, Allende E: Non-Hodgkin's lymphoma after liver transplantation: response to chemotherapy. Med Pediatr Oncol 1996, 27(3):156-159.

3. Clarke CA, Morton LM, Lynch C, Pfeiffer RM, Hall EC, Gibson TM, Weisenburger DD, Martinez-Maza O, Hussain SK, Yang J et al: Risk of lymphoma subtypes after solid organ transplantation in the United States. Br J Cancer 2013, 109(1):280-288.

4. Taylor AL, Marcus R, Bradley JA: Post-transplant lymphoproliferative disorders (PTLD) after solid organ transplantation. Critical reviews in oncology/hematology 2005, 56(1):155-167.

5. Huang Q, Yang T, Jin X, Ni X, Qi H, Yan Z: Remission of late-onset post-heart transplantation lymphoproliferative disorder following treatment with rituximab and modified mini-CHOP chemotherapy: A case report. Experimental and therapeutic medicine 2016, 12(1):262-266.

6. Campo E, Swerdlow SH, Harris NL, Pileri S, Stein H, Jaffe ES: The 2008 WHO classification of lymphoid neoplasms and beyond: evolving concepts and practical applications. Blood 2011, 117(19):5019-5032.

7. Kinch A, Baecklund E, Backlin C, Ekman T, Molin D, Tufveson G, Fernberg P, Sundstrom C, Pauksens K, Enblad G: A population-based study of 135 lymphomas after solid organ transplantation: The role of Epstein-Barr virus, hepatitis $\mathrm{C}$ and diffuse large $\mathrm{B}$-cell lymphoma subtype in clinical presentation and survival. Acta Oncol 2014, 53(5):669-679.

8. Ghobrial IM, Habermann TM, Maurer MJ, Geyer SM, Ristow KM, Larson TS, Walker RC, Ansell SM, Macon WR, Gores GG et al: Prognostic analysis for survival in adult solid organ transplant recipients with post-transplantation lymphoproliferative disorders. J Clin Oncol 2005, 23(30):7574-7582.

9. Luskin MR, Heil DS, Tan KS, Choi S, Stadtmauer EA, Schuster SJ, Porter DL, Vonderheide RH, Bagg A, Heitjan DF et al: The Impact of EBV Status on Characteristics and Outcomes of Posttransplantation Lymphoproliferative Disorder. Am J Transplant 2015, 15(10):2665-2673.

10. Morscio J, Dierickx D, Ferreiro JF, Herreman A, Van Loo P, Bittoun E, Verhoef G, Matthys P, Cools J, Wlodarska I et al: Gene expression profiling reveals clear differences between EBV-positive and EBV-negative posttransplant lymphoproliferative disorders. Am J Transplant 2013, 13(5):1305-1316.

11. van Leeuwen MT, Grulich AE, Webster AC, McCredie MR, Stewart JH, McDonald SP, Amin J, Kaldor JM, Chapman JR, Vajdic CM: Immunosuppression and other risk factors for early and late non-Hodgkin lymphoma after kidney transplantation. Blood 2009, 114(3):630-637.

12. Opelz G, Dohler B: Lymphomas after solid organ transplantation: a collaborative transplant study report. Am J Transplant 2004, 4(2):222230.

13. Engels EA, Pfeiffer RM, Fraumeni JF, Jr., Kasiske BL, Israni AK, Snyder JJ, Wolfe RA, Goodrich NP, Bayakly AR, Clarke CA et al: Spectrum of cancer risk among US solid organ transplant recipients. JAMA 2011, 306(17):1891-1901.

14. Quinlan SC, Pfeiffer RM, Morton LM, Engels EA: Risk factors for early-onset and late-onset post-transplant lymphoproliferative disorder in kidney recipients in the United States. Am J Hematol 2011, 86(2):206-209.

15. Dierickx D, Habermann TM: Post-transplantation lymphoproliferative disorders in adults. New England Journal of Medicine 2018, 378(6):549-562.

16. Khedmat H, Taheri S: Lymphoproliferative disorders in pediatric liver allograft recipients: a review of 212 cases. Hematology/oncology and stem cell therapy 2012, 5(2):84-90.

17. Ito K, Siegelman ES, Stolpen AH, Mitchell DG: MR imaging of complications after liver transplantation. American Journal of Roentgenology 2000, 175(4):1145-1149.

18. Geissler EK, Schlitt HJ: Immunosuppression for liver transplantation. Gut 2009, 58(3):452-463.

19. Rodriguez-Peralvarez M, Guerrero-Misas M, Thorburn D, Davidson BR, Tsochatzis E, Gu- 
rusamy KS: Maintenance immunosuppression for adults undergoing liver transplantation: a network meta-analysis. Cochrane Database Syst Rev 2017, 3:CD011639.

20. Al-Mansour Z, Nelson BP, Evens AM: Post-transplant lymphoproliferative disease (PTLD): risk factors, diagnosis, and current treatment strategies. Current hematologic malignancy reports 2013, 8(3):173-183.

21. Cockfield $\mathrm{S}$ : Identifying the patient at risk for post-transplant lymphoproliferative disorder. Transplant infectious disease 2001, 3(2):70-78.

\title{
Резиме
}

\section{РЕМИСИЈА НА ЗАДОЦНЕТО ПОЈАВЕН НОН-ХОЏКИН ЛИМФОМ КАЈ ПАЦИЕНТ СО ТРАНСПЛАНТАЦИЈА НА ХЕПАР - ПРИКАЗ НА СЛУЧАЈ}

\author{
Калина Гривчева Старделова ${ }^{1}$, Александар Стојановиќ ${ }^{2}$, Розалинда Попова Јовановска ${ }^{1}$, \\ Соња Ставриќ ${ }^{2}$, Магдалена Димитрова ${ }^{1}$, Неда Милевска Костова ${ }^{3}$, Владимир Серафимоски ${ }^{4}$ \\ ${ }^{1}$ Универзитетска клиника за гастроентерохепатологија, Универзитет „Св. Кирил и Методиј“ \\ Скопје, Република Македонија \\ 2 Универзитетска клиника за хематологија, Универзитет „Св. Кирил и Методиј“, Скопје, \\ Република Македонија \\ ${ }^{3}$ Центар за регионални истражувања и соработка „Студиорум“, Скопје, Република Македонија \\ ${ }^{4}$ Македонска академија на науките и уметностите, Скопје, Република Македонија
}

Во нашата студија е презентиран случај на пациент што развива високоагресивен лимфом како резултат на имуносупресивна терапија со циклоспорин А, по трансплантација на хепар, и тој е изложен на антинеопластичен полихемиотераписки третман, со што е постигната и одржана целосна ремисија.

Пациентот е 27-годишна жена, на која ѝ е извршена трансплантација на црн дроб на 17-годишна возраст, со акутна хепатална инсуфициенција предизвикана од недијагностицирана Вилсонова болест. По посттрансплантацискиот период од седум години, на пациентката ѝ е дијагностициран нон-Хоџкин лимфом, потенцијално индуциран од имуносупресорна терапија со цефалоспорин А. По третман co rituximab и СНОР-терапија (r-CHОР протокол), утврдена е ремисија со помош на компјутерска томографија, која е одржана до денес.

Прегледот на литературата и на слични случаи на посттрансплантациски лимфопролиферативни нарушувања (ПТЛД) покажа дека кај пациентите со трансплантација на хепар (ЛТ) појавата на ПТЛД има највисока инциденца во првата година по трансплантацијата. Дополнително, не постојат доволно податоци во литературата за ремисија на нон-Хоџкин лимфома кај ЛТ-пациенти.

Наш заклучок е дека презентираниот случај е редок во споредба со податоците во литературата објавени во оваа област, како од аспект на времето на појава на ПТЛД така и од аспект на постигнатата ремисија со r-CHОР протокол.

Клучни зборови: хепар, трансплантација, лимфом, нон-Хоџкин, имуносупресија 